\title{
A REVISÃO CONSTITUCIONAL E PEC 157-A/03: (IN)CONSTITUCIONALIDADE E MANOBRA POLÍTICA
}

\author{
Júlio Canello ${ }^{1}$
}

RESUMO: O presente artigo analisa a Proposta de Emenda à Constituição 157-A/03, em tramitação na Câmara dos Deputados, no bojo da discussão acerca da revisão constitucional. Como abordagem, tenta unir enfoques da dogmática constitucional e da análise política. Assim, debate a constitucionalidade da proposição e do seu uso como manobra pelos atores políticos no Congresso Nacional.

PALAVRAS-CHAVE: Revisão Constitucional, Poder Constituinte, processo legislativo.

\section{The Constitutional Review and the PEC 157-A/03: (un)constituctionallity e political stratagem}

ABSTRACT: This paper analyse the PEC 157-A/03, presented in the Brazilian Chamber of Deputies, in the midlle of the constitucional review disscussion. As aproach, tries to use constitucional dogmatics and political analysis. This way, the text debates the proposal's constitutionallity and it's uses as political stratagem.

KEY-WORDS: Constitutional review, representative power, legislative process.

\footnotetext{
${ }^{1}$ Acadêmico dos Cursos de Direito e Ciências Sociais na UFSM. E-mail: julio_canello@yahoo.com.br.
} 


\section{Introdução}

Recentemente, o Presidente Luis Inácio Lula da Silva, em reunião com juristas (alguns destes ex-presidentes da $\mathrm{OAB}$ ), demonstrou interesse em convocar uma "Mini-Assembléia" Constituinte exclusiva para a reforma política. Não tardou para que a oposição, a própria OAB, parcela significativa da comunidade jurídica e mesmo parte da base do governo rejeitassem a idéia. De pronto, o próprio governo a descartou, reforçando sua posição quanto à necessidade da reforma política. Entretanto, a idéia de revisar a constituição ou de alterar regras constitucionais através de outros expedientes diversos da Emenda à Constituição não é nova.

A época da elaboração desse texto, tramita na Câmara dos Deputados a Proposta de Emenda à Constituição no 157-A/03 visando a instalar Assembléia de Revisão Constitucional, que iniciaria seus trabalhos em 2007. Assim, dada a tramitação de tal matéria, bem como a recolocação do assunto com a declaração presidencial, relevante é discutir, brevemente, a viabilidade e intenções de tais propostas. O objetivo desse artigo é, dessa forma, investigar, minimamente, a tramitação e os debates acerca da proposta de revisão constitucional ora no Congresso Nacional, analisando aspectos quanto à sua constitucionalidade e intenções dos atores políticos. A abordagem utilizada nesse texto tenta unir enfoques jurídicos e políticos, na medida em que analisa e relaciona considerações do ponto de vista da dogmática constitucional e do enfrentamento político dos atores.

A motivação para a elaboração do texto nasceu antes da retomada recente do debate pela declaração do Presidente da República. Surgiu com a oportunidade do autor em presenciar sessão da Comissão Especial de Revisão Constitucional, na ocasião da apresentação do voto do Relator e de votos contrários. Ainda, o tema, sobretudo em seu debate de fundo quanto ao Poder Constituinte, é fundamental no campo do Direito Constitucional.

$\mathrm{O}$ artigo divide-se em duas seções e rápidas considerações finais. Na primeira, apresenta-se a tramitação da PEC 157-A/2003, o contexto do debate, as posições defendidas e seus argumentos. Em seguida, investiga-se a discussão de fundo quanto à doutrina constitucional e a atuação política dos atores. Por fim, resume-se o argumento elaborado, com vistas ao cenário atual.

\section{A tramitação}

A primeira seção deste texto discorre sobre a tramitação da Proposta de Emenda à Constituição 157-A/03 na Câmara dos Deputados. Analisa não somente os momentos do 
processo legislativo pelo qual já passou, como também que modificações sofreu e que posições foram defendidas por quem em cada momento. Assim, verifica o trâmite da proposição tanto do ponto de vista processual quanto de análise política. A intenção é, de tal forma, situar o leitor no debate efetivamente travado sobre a revisão constitucional na Casa.

Primeiramente, cabe informar que a PEC aqui examinada não é a primeira elaborada nesse sentido após a Constituição de 1988. Ressalta-se a Proposta de Emenda à Constituição 554/1997, de autoria do Deputado Milton Teixeira (PDT-RJ). Essa também pretendia convocar uma Assembléia Nacional Revisora, formada pelos Deputados e Senadores, com trabalhos no ano de 1999. Apresentava muita semelhança com a atual proposta, distinguindo-se em alguns pontos, como nos dispositivos passíveis de reforma e na realização de plebiscito prévio a sua instalação. Todavia, mesmo sendo aprovada pelas Comissões em que tramitou e estando pronta para a pauta no Plenário da Câmara, tal matéria não foi votada e transformada, efetivamente, em Emenda Constitucional. O tempo passou e o ano de 1999 adveio sem Revisão Constitucional.

Importa, também, referir que a pretensão de realizar nova revisão constitucional esteve por bom tempo latente em alguns grupos políticos. Desde os debates da Constituinte e após a promulgação da Constituição de 1988, significativo setor liberal manifestou o posicionamento de que a extensão e o detalhamento da nova Carta trazia em seu bojo uma grande regulamentação estatal, bem como promessas que não seriam cumpridas². Mesmo após a Revisão Constitucional de 1993 e mais 52 Emendas à Constituição aprovadas, tal setor não conseguiu sair vitorioso nessa disputa. Assim, a uma primeira vista, a atual proposta parece ser encabeçada pelos defensores dessa posição.

Como dito, tramita na Câmara dos Deputados a Proposta de Emenda à Constituição 157-A/2003 que "convoca Assembléia de Revisão Constitucional e dá outras providências". Trata-se de proposição de autoria do Deputado Luiz Carlos Santos (PFL-SP) mais 174 deputados que prevê sua instalação em $1^{\circ}$ de fevereiro de 2007 , formada pelos deputados e senadores que serão eleitos no pleito de 2006. Teria, originalmente, o propósito de revisar a Constituição, resguardadas as cláusulas pétreas, em observância ao disposto no art. $60, \S 4^{\circ}$.

\footnotetext{
${ }^{2}$ Em obra sobre o pensamento político de Roberto Campos, Perez (1999, pp 225-226) ao versar sobre esse período histórico assinala: "a pequena parcela de parlamentares identificada com o economicismo liberal foi derrotada nas batalhas da ANC". Ainda em Perez (1999, p. 226): "Campos está motivado pelo liberalismo econômico de Hayek; os centristas guardam semelhança com o liberalismo ético-político de Bobbio. Estes últimos venceram a luta ideológica na ANC".
} 
Decisivamente propõe maior facilidade para a aprovação das proposições, reduzindo o atual quorum de $3 / 5^{3}$ para a maioria absoluta dos membros, em dois turnos de votação unicameral.

Na justificativa, o autor da proposta argumenta pela necessidade da Revisão Constitucional tendo em vista o "caráter excessivamente analítico" e o "alto nível de detalhamento" da Carta. Denota, inclusive, sua posição quanto às mudanças necessárias ao afirmar que "filigranas previdenciárias, administrativas e tributárias espraiam-se por toda a extensão da Carta, suscitando obstáculos, embaraços e impedimentos de toda ordem. A toda evidência, a Constituição brasileira exacerba da tarefa de impor limites aos poderes públicos, constituindo-se em poderoso instrumento de ingovernabilidade” (Santos, 2003).

Nítida é, também, a argumentação em torno da "ingovernabilidade" resultante das normas constitucionais em vigência. Adiante, indica como problema o número excessivo de Emendas já realizadas e ainda em tramitação, apontando para uma "instabilidade jurídica" e "déficit de seu valor e força normativa". Por fim, ilustra sua justificativa citando o cientista político italiano Giovani Sartori e o ilustre doutrinador Konrad Hesse. Termina sua argumentação afirmando que:

Nesse sentido, a presente proposta tem por objetivo instituir regime especial de reforma da Constituição, ofertando ao país nova oportunidade de proceder tão necessária profilaxia constitucional. Mediante a convocação de uma Assembléia de Revisão Constitucional, busca-se corrigir rumos, adequar instituições, eliminar artificialidades e pormenores, revitalizando o primado do Estado de Direito e a governabilidade do país. (Santos, 2003)

Apresentada pelo autor, a PEC seguiu, conforme o trâmite devido, à Comissão de Constituição, Justiça e Cidadania (CCJC) para que proferisse o juízo de admissibilidade. A matéria teve como relator o Deputado e jurista Michel Temer (PMDB-SP), que em seu parecer apresentou substitutivo aprovado com unanimidade pela Comissão.

O substitutivo teve como justificação a necessidade de adequação da proposta original para que ficasse assegurada a constitucionalidade da matéria. As mudanças referiram-se ao procedimento para a instalação da Assembléia e direção dos trabalhos até a eleição da presidência; a discussão unicameral, mas a votação separadamente entre Deputados e Senadores, em dois turnos; o acréscimo à observância do art. $60, \S 4^{\circ}$ da não modificação do Título II, Capítulo III da Constituição Federal, que se refere aos direitos sociais; a autorização

\footnotetext{
${ }^{3}$ Tal quorum refere-se ao utilizado para as Emendas à Constituição, previsto no art. $60, \S 2^{\circ}$ da C.F.
} 
da realização de Revisões Constitucionais periódicas a cada dez anos; bem como a sujeição das mudanças a referendo popular findo os trabalhos da Assembléia. Mantiveram-se as datas, o prazo e o quorum de maioria absoluta para aprovação das matérias.

Como era de se esperar, o parecer de Michel Temer apresenta boa fundamentação. Ao defender o substitutivo apresentado, manifesta-se pela adequação da proposta a condições de constitucionalidade. O acréscimo do referendo popular é sustentado pelo argumento de que o povo tem a titularidade e o exercício do poder constituinte, com fundamento no parágrafo único do art. $1^{\circ}$ da CF, que, para Temer (2005), tem duas significações "uma, a de indicar quem é o titular do poder que fez editar a Constituição; outra, a de indicar um poder constituinte latente que pode ser convocado para convalidar atos regulares, autorizados pela Constituição, ou outros que, embora constantes de cláusulas pétreas, possam ser alterados sem que se revogue o princípio nelas contido".(Temer, 2005)

Reforça seu ponto de vista quanto ao assunto citando doutrina de Celso Ribeiro Bastos, Manoel Gonçalves Ferreira Filho e do professor Alexis Vargas em sua dissertação de mestrado. Defende o uso do referendo e não do plebiscito que, segundo o Relator, seria "um cheque em branco" aos revisores. Entende, ainda, que dado o nível de acesso a informações hoje existente não seria possível a manipulação da "massa", como no fascismo e nazismo. Também, acrescenta a impossibilidade de supressão dos Direitos Sociais com seu substitutivo e a realização de nova revisão constitucional a cada dez anos afirmando que "o engessamento rigoroso da Lei Magna pode levar a indesejáveis rupturas institucionais” (Temer, 2005).

$\mathrm{O}$ argumento central do parecer pela admissibilidade da proposta com o substitutivo é a tese do conteúdo conceitual das cláusulas pétreas explícitas e implícitas. Ponto de vista que afirma não haver agressão às cláusulas pétreas se seus princípios persistirem. Temer (2005) discorre sobre o tema da seguinte forma:

Seja: se no caso das cláusulas explícitas sustento que não há violação principiológica desde que mantido o conceito adotado pelo constituinte, também não vejo, nas cláusulas pétreas implícitas, agressão à rigidez constitucional se o princípio mantiverse intacto.

Tudo isto para salientar que continuará inalterado o processo de modificação constitucional, "petrificado" implicitamente, se a rigidez, ou seja, o processo especial, qualificado, dificultoso, diferenciado em relação às leis ordinárias e complementares for mantido.(Temer, 2005) 
Em outro momento, ao defender alterações pontuais desde que mantidos os princípios, exemplifica: "não há violação ao princípio federativo se houver alteração de competências tributárias entre os entes federativos. Seja: se a autonomia dos entes federativos persiste nada importa que haja uma redução competencial de um deles em favor do outro" (Temer, 2005).

No parecer, o relator também manifesta, em diversos momentos, sua mudança de posição quanto ao tema da revisão constitucional. Primeiramente, indica na vivência política seus motivos:

Confesso que já tive simpatia e cheguei a adotar essa tese da invariabilidade absoluta do princípio tripartidor do Poder. Mas a vivência política, o trato com os problemas nacionais, com o cotidiano administrativo e, especialmente com a necessidade de mantença da Constituição, sem a necessidade de convocação de uma Constituinte, levou-me a flexibilizar tal conceituação. (Temer, 2005)

Em momento seguinte, ao defender seu ponto de vista, faz breve ataque ao formalismo e informa sua mudança de posicionamento:

Não posso deixar de registrar que o tema comportará muitas discussões e objeções. Já defendi, formalista que fui na interpretação Constitucional, a absoluta inviabilidade de alteração senão pela via da manifestação Congressual numericamente estabelecida no Texto Magno. Mas todas as lições e concepções aqui expostas voltam a revelar que há um poder constituinte latente no povo que, no caso da Constituição atual não apenas o titulariza mas também o exerce diretamente.(Temer, 2005)

Apresentado o parecer e o Substitutivo pelo relator Michel Temer, a CCJC o aprovou por unanimidade. Em seguida, a proposição foi encaminhada para a Comissão Especial destinada a proferir parecer à PEC 157/03, seguindo o trâmite regimental ${ }^{4}$.

Nessa fase da tramitação, a Comissão Especial recebeu quatro Emendas à proposta apresentada. Três delas foram de autoria do Deputado Henrique Fontana (PT-RS). Uma definia a instalação da Assembléia Revisora para 2011; outra extinguindo a possibilidade de revisão periódica a cada dez anos; e a última aumentando o número de dispositivos constitucionais imunes à revisão. Ainda, a Emenda restante foi proposta pelo Deputado João Alfredo (PSOL$\mathrm{CE}$ ), na forma de substitutivo, alterando as datas da instalação, mas mantendo o ano; criando a

\footnotetext{
${ }^{4}$ O Regimento Interno da Câmara dos Deputados prevê em seu art. 202, §2 que se o juízo de admissibilidade for favorável, o Presidente designará Comissão Especial para o exame do mérito da proposição, em casos de Propostas de Emenda à Constituição.
} 
necessidade de autorização para funcionamento por plebiscito; e tendo como ponto central a impossibilidade da revisão restringir os direitos e garantias atualmente assegurados.

No decorrer dos debates da Comissão Especial foi apensada a PEC 447/05 do Deputado Alberto Goldman (PSDB-SP) que também visava convocar Assembléia de Revisão Constitucional para 2007, contudo formada por representantes eleitos em 2006 com mandato de dois anos e vedada eleição para o Congresso Nacional no pleito de 2010.

Também, foram realizadas audiências públicas para a discussão da matéria. Nestas foram ouvidos os professores Fábio Konder Comparato (Universidade de São Paulo) e José Geraldo de Souza Júnior (Universidade de Brasília), e o ex-ministro do STF Nelson Jobim. Os dois primeiros manifestaram-se contrários à PEC e à revisão constitucional, sendo o último favorável. Em outra audiência, por fim, foram ouvidos representantes da $\mathrm{OAB}$ e de partidos políticos.

$\mathrm{Na}$ Comissão Especial a matéria teve como relator o Deputado Roberto Magalhães (PFL-PE) que emitiu parecer pela aprovação da PEC 157-A/03, nos termos do substitutivo; pela não aprovação da PEC 447/05, em apenso; pela aprovação da Emenda $\mathrm{n}^{\circ} 2$ (referente à revisão periódica) e rejeição das demais.

No voto a argumentação inicia remetendo à discussão doutrinária acerca do poder constituinte originário e derivado. Nesse ponto, o relator (Magalhães, 2006) alicerça-se em citações de Ricardo Arnaldo Malheiros Fiuza, Emmanuel Joseph Sieyès, Jorge Miranda e José Afonso da Silva. Em seguida, discorre sobre as Constituições brasileiras e suas mudanças e, por fim, retoma argumentos do parecer do Deputado Michel Temer para manifestar posição favorável à possibilidade de Revisão Constitucional.

Segue tratando sobre a necessidade e oportunidade da revisão. Para tal lembra a exposição do ex-ministro Nelson Jobim que defendeu uma "lipoaspiração" na Constituição de 1988, bem como a justificação da proposta pelo Deputado Luiz Carlos Santos ao afirmar que:

a significativa mudança dos rumos políticos do País, simbolizada pela Constituição de 1988, contrasta com as dificuldades técnicas e políticas que o seu texto introduziu, chegando a afirmar que a nossa Constituição exacerba a tarefa de impor limites aos poderes públicos, constituindo-se em poderoso instrumento de ingovernabilidade. [...] a urgente necessidade de eliminar a insegurança jurídica que se instalou neste País após a Carta de 1988. [...] a Revisão Constitucional poderá estancar a enxurrada de mudanças pontuais da Carta, buscando introduzir alterações importantes de forma sistêmica e racional. (Magalhães, 2006) 
Entretanto, o que transparece em seu voto, é o que parece ser uma preocupação central dos propositores da idéia, a redução do quorum para a aprovação das modificações à Constituição. Tal preocupação fica visível ao afirmar que:

O quorum de maioria absoluta ficou mantido, apesar de ter reivindicações no sentido do quorum de três quintos, porque, em face da nova sistemática, que prevê uma revisão restrita, se o quorum for elevado para três quintos, não haverá diferença entre a revisão pretendida e as emendas constitucionais já previstas no art. 60 (Magalhães, 2006).

Por fim, o texto final votado na Comissão Especial segue o substitutivo de Michel Temer, delimitando as matérias objeto da Revisão Constitucional na organização dos Poderes; sistema eleitoral e partidário; sistema tributário nacional e finanças públicas; organização e competências das unidades da federação; e sistema financeiro nacional.

Foram apresentados quatro Votos Contrários em separado. Defenderam, na Comissão Especial, a rejeição da PEC, de tal maneira, os deputados Luiz Eduardo Greenhalgh (PT-SP), Jamil Murad (PC do B - SP), Alceu Collares (PDT-RS) e João Alfredo (PSOL-CE).

Greenhalgh (2006), em seu voto acompanhado pelos Deputados Antônio Carlos Biscaia e Odair Cunha, buscou refutar a proposta iniciando pelo ataque as suas justificativas. Negou o caráter excessivamente analítico da Carta de 1988 e suas possíveis implicações como instrumento de ingovernabilidade. Destacou, ou citar o caso da Constituição dos Estados Unidos, a importância da interpretação das normas constitucionais. Ou seja, a perpetuidade da Constituição estaria ligada à tarefa de interpretação e sua força normativa à aplicação de suas disposições. Nesse ínterim, citou Karl Loewenstein para indicar o desprestígio da Constituição pela inércia dos órgãos constituídos em sua aplicação.

Também, argumentou o esgotamento da possibilidade de realizar-se revisão constitucional novamente, tendo em vista o modelo inscrito no art. $3^{\circ}$ da ADCT. Realizar-se-ia, pela nova Carta, apenas uma revisão passados cinco anos de sua promulgação, o que já fora efetuado. A revisão seria única, optando o legislador constituinte pelo caminho da Emenda à Constituição nos demais momentos. Para sustentar a rejeição da matéria utiliza-se também de citação de artigo do Deputado Michel Temer, quando em sua antiga opinião.

Entende o voto pela ausência dos pressupostos para a convocação do poder constituinte originário. Tal posição é clara na seguinte passagem: somente quando ocorrem rupturas na ordem política instituída é que entram em cena as assembléias constituintes, com o objetivo de institucionalizar, através do documento solene, a constituição, a nova ordem político- 
jurídica.(Greenhalgh, 2006) Por fim, defende a estabilização do Estado e o resguardo à Constituição como forma de preservação dos valores essenciais e avanços sociais esculpidos na Carta.

O voto do Deputado Jamil Murad (2006) segue argumentação próxima. Acrescenta que não seria aplicado o exemplo da Emenda à Constituição 26/85, que convocou a Constituinte, para a revisão constitucional ora proposta, posto que não há mudança profunda na ordem política e institucional brasileira. Identifica inconstitucionalidades na proposta ora apresentada, tanto no concernente ao titular do poder de emenda quanto ao procedimento para alteração do texto, considerando as limitações materiais ao poder de reforma. Para tal fundamenta-se nas doutrinas de José Afonso da Silva, Paulo Bonavides e Celso Ribeiro Bastos.

Nega, na sua argumentação, a existência de insegurança jurídica decorrente da Carta de 1988. Ao contrário, inverte o argumento afirmando que a proposta de revisão constitucional é que seria capaz de promover tal insegurança. Aponta também nesse sentido, embora timidamente, a questão do quorum:

Se para afrontar o texto constitucional determinados interesses políticos esforçam-se em arregimentar uma discutível e momentânea maioria qualificada de três quintos, é certo que estes mesmos interesses poderão ampliar o âmbito das modificações constitucionais. Dessa forma, o país passa a viver em profunda insegurança sobre quais normas os constituintes revisores considerariam matéria conexa aos artigos relacionados no $\$ 2^{\circ}$ do art. 75 do ADCT acrescido pela PEC em questão. (Murad, 2006)

Por fim, denuncia o uso do plebiscito ou referendo como fraude ao afirmar que (Murad, 2006) invocar a participação popular como meio de legitimação de uma afronta a uma norma constitucional limitada ao poder de reforma representa inegável vício de inconstitucionalidade. Ao votar contrariamente à matéria propõe uma "denúncia à nação".

O voto do Deputado João Alfredo (2006) também segue argumentação semelhante. Espanta-se pela aprovação unânime da matéria na CCJC. Acrescenta uma discussão acerca da possibilidade daquela Comissão ter apresentado emenda por seu relator, visto que se tratava de juízo de admissibilidade. Mostra temor quanto à fragilidade resultante da mudança do quorum e indica incompatibilidade com o art. 16 da Constituição Federal ${ }^{5}$.

\footnotetext{
${ }^{5}$ No sentido de que tal emenda seria entendida como alteração do processo eleitoral na medida em que tornaria os novos representantes também revisores, de tal forma que afrontaria o citado dispositivo por não respeitar o prazo de um ano para mudanças em regras eleitorais.
} 
Reforça o argumento do esgotamento da possibilidade de revisão constitucional, dado pelo art. $3^{\circ}$ da ADCT. Em suma, afirma que a proposta em voga significa ruptura institucional e que seria um retrocesso para a classe trabalhadora e mais um passo para o avanço da hegemonia neoliberal.

Por fim, o Deputado Alceu Collares (2006) também reforça a argumentação já delineada, retomando diversos pontos. Cita abalizada doutrina, de Sieyès, Hesse e Lassale a José Afonso da Silva, Fábio Konder Comparato e Nelson de Souza Sampaio, dentre outros. Ataca o parecer do relator ao insinuar que as "novas necessidades" apontadas seriam as do Poder Executivo. Indica como frágil a argumentação sobre o excesso de Emendas Constitucionais e trata como golpismo a redução do quorum. Ao discutir os termos do exministro Nelson Jobim de que (Collares, 2006) "todas as constituições brasileiras foram sempre processo de transição" lembra que, em parte de nossa história, tais transições foram, em geral, autoritárias e opressoras.

Posta-se contrário ao referendo, defendendo - ao inverso - o plebiscito e denotando que a proposta em questão serve à conveniência do Poder Executivo. Também, manifesta-se pela insegurança jurídica como o resultado de uma possível revisão e não o estado atual das coisas. Refere-se também à revisão como contrária às garantias e direitos ora constitucionalmente firmados: "Não vemos na revisão constitucional o arcabouço que pretenda salvaguardar ou avançar nas garantias e direitos insculpidos na Carta de 1988, tampouco a solução para o problema institucional que afirmam existir, muito menos com as reformas pretendidas, ensejando, muito mais, um apego formal à oportunidade" (Collares, 2006). De tal forma, vota contrariamente.

Contudo, apesar de tais manifestações, a PEC 157/03 foi aprovada pela Comissão Especial nos termos apresentados pelo parecer do Relator, conforme o substitutivo de Michel Temer na CCJC. Posta em votação pela primeira vez em 03 de maio de 2006 - ocasião na qual faltou quorum para deliberação - a matéria somente foi aprovada em 10 de maio. No momento em que o artigo é feito, encontra-se na Coordenação de Comissões Permanentes da Câmara dos Deputados aguardando encaminhamento e sujeita à apreciação do Plenário.

Pelo exemplo da PEC 554/97 e dado à conjuntura eleitoral é pouco provável que a matéria seja apreciada em Plenário antes de passado o período de instalação da Assembléia Revisora previsto na própria Proposta. De qualquer forma, importa atentar mais 
cuidadosamente para as implicações da matéria, posto o tema que enfrenta e a recorrência do debate acerca da revisão constitucional.

\section{Questão de fundo}

Esta seção busca abordar o tema proposto unindo a dogmática constitucional e a análise política. Num primeiro momento far-se-á breve discussão acerca do Poder Constituinte, rigidez constitucional e sobre a constitucionalidade da proposta. Em seguida proceder-se-á a rápida análise do ponto de vista político acerca dos atores envolvidos no encaminhamento da PEC, possíveis interesses e implicações.

Antes, porém, cabe salientar a repercussão da matéria na comunidade acadêmica e entre os operadores do direito. De um modo geral, poucas foram (e são) as vozes abertamente favoráveis à proposta. Salvo o apoio considerável do ex-ministro do STF Nelson Jobim, a maioria da comunidade jurídica manifestou-se contrária à idéia. Nessa linha destaca-se o manifesto de Streck; Cattoni et al (2006) intitulado "Revisão é golpe! Porque ser contra a proposta de revisão constitucional". Clara é a opinião dos autores pela inconstitucionalidade da matéria e sobre qual seria sua pretensão:

É preciso deixar claro que a PEC 157, que visa à redução do quorum de três quintos para maioria absoluta, à diminuição dos turnos de votação, bem como à reunião unicameral das Casas Legislativas, enfim, a uma simplificação do processo legislativo de reforma, é inconstitucional, estando sujeita à declaração de inconstitucionalidade pelo Poder Judiciário. Tão inconstitucional que o porteiro do STF deveria declará-la, dispensando-se os Ministros da Corte de apreciar tamanha heresia. (Streck; Cattoni et al, 2006)

Semelhante é a posição quanto a atual proposta manifestada pelo Presidente da República. Apesar de, agora, tratar-se de uma Assembléia Constituinte exclusiva, com eleições próprias, as opiniões, em geral, não divergem muito. Exceto, talvez, na manifestação de Ives Granda Martins a idéia ora em voga também não tem encontrado guarida. Não somente a oposição tem declarado contrariedade à iniciativa, mas parcela da própria base do governo e, sobretudo, a comunidade de intérpretes da Constituição. Há, inclusive, declarações fortes como a do ex-ministro do STF Celso Velloso ao dizer que tal convocação "cheira a golpe”. 


\subsection{Do Poder Constituinte e da Constitucionalidade da proposta}

A discussão da matéria que tramita na Câmara dos Deputados e da manifestação presidencial remete a uma questão de fundo no Direito Constitucional. Trata-se, principalmente, de um problema candente ao Poder Constituinte, à rigidez constitucional e à revisão da Constituição. Ou seja, busca-se saber se a convocação de uma Assembléia de Revisão Constitucional (ou mesmo uma Assembléia Nacional Constituinte exclusiva) pode ser aceita, se tal procedimento é constitucional ou não.

Cabe ressaltar o entendimento doutrinário acerca da atual Constituição. Tem-se que se trata de espécie rígida, compreendendo-se, conforme Silva (2003, p. 45), que a "rigidez constitucional decorre da maior dificuldade para sua modificação do que para a alteração das demais normas jurídicas da ordenação estatal". Tal classificação é conseqüência, portanto, da existência de um procedimento mais tortuoso para a alteração do texto constitucional do que para a edição de Lei ordinária. Trata-se da Emenda à Constituição. Dessa forma, uma das garantias da rigidez da Carta de 1988 é dada pelas restrições formais a sua alteração, em outras palavras, pelas maiores exigências na proposição e tramitação das Emendas Constitucionais.

Entende-se que mesmo sendo rígida, pode-se modificar a Constituição. Silva (2003) denomina reforma constitucional o gênero que abarca as espécies revisão e emenda à constituição. Miranda (2002) denomina o mesmo fenômeno de revisão constitucional, tratando a emenda como uma forma possível de procedimento deste. Importa destacar que a revisão ou reforma não se confunde com a mutação constitucional, entendida como processo não formal de mudança. Dessa forma, foca-se a questão das alterações formais no texto.

A Constituição de 1988 prevê duas maneiras de reforma: a Emenda Constitucional e a Revisão Constitucional única. A primeira está prevista em seu art. 60 e a segunda no art. $3^{\circ}$ do Ato das Disposições Constitucionais Transitórias. Esta, como previsto, realizou-se após cinco anos da promulgação da Constituição, em sessão unicameral do Congresso Nacional, decidindo pela maioria absoluta dos membros. Posto que norma transitória, e já tendo sido realizada tal revisão, sua eficácia encontra-se esgotada. Não mais é possível realizar nova revisão constitucional. Assim, “qualquer mudança formal na Constituição só deve ser feita legitimamente com base no seu art. 60, ou seja, pelo procedimento das emendas com os limites dali decorrentes" (Silva, 2003, p. 62) . Conclui-se, desta maneira, que o único procedimento formal de reforma constitucional ora admitido é a Emenda à Constituição. 
Num primeiro momento poder-se-ia aderir a tese que entende inconstitucional a PEC 157/03, visto já existir um procedimento formal de reforma e tendo a eficácia da revisão se esgotado. De qualquer forma, cabe aprofundar um pouco mais a discussão do ponto de vista doutrinário. Para isso merece tratamento a teoria do Poder Constituinte.

Para Moraes (2001, p.52), “o Poder Constituinte é a manifestação soberana da suprema vontade política de um povo, social e juridicamente organizado. A doutrina aponta a contemporaneidade da idéia de Poder Constituinte com a do surgimento de Constituições escritas, visando à limitação do poder estatal e a preservação dos direitos e garantias individuais". A primeira formulação densa do conceito foi realizada pelo francês Sieyès pouco antes da revolução francesa. A esse poder cabe elaborar a Constituição do Estado. Há, nessa doutrina, a divisão entre o poder constituinte e os poderes constituídos. No pensamento do autor francês, ela decorre de suas inspirações liberais. Eis, em Chatelet (1993), a origem de tal distinção. Sendo a Nação titular do poder constituinte, ela tem a competência e os poderes para limitar a atuação dos governantes (que exercem os poderes constituídos).

Embora, à época da revolução francesa, propunha-se que a titularidade do poder constituinte devesse pertencer à Nação (entendida não apenas como o conjunto de indivíduos, mas também dotada de uma vontade ou senso de comunidade), na realidade histórica esta pertenceu também a outros grupos políticos. Desde ao monarca, às oligarquias de vários tipos ou às elites ou grupos militares. Contemporaneamente, em nosso país, entende-se que o povo é seu titular.

O poder constituinte, que pertence ao povo, elabora a Constituição por meio de seus representantes em Assembléia. Nesse ato cria também os poderes constituídos ou instituídos (Executivo, Legislativo e Judiciário). Tal é o que, doutrinariamente, passou-se no processo constituinte que originou a Carta de 1988. Dessa forma, os poderes instituídos submetem-se ao constituinte. Disso decorre as diferentes características de cada um, trazidas pela doutrina. $\mathrm{O}$ poder constituinte, conforme, Ferraz Junior (1985, p.22) "seria um Poder de fato, que se supõe legítimo porque baseado na vontade popular, inicial, porque a partir dele é que se estabelecem as normas de exercício do poder, autônomo, porque não limitado por outras normas postas, e incondicionado, porque não tem nenhuma forma preestabelecida para manifestar-se". Já o poder instituído, de acordo com Moraes (2001, p.55), seria:

derivado porque retira sua força do Poder Constituinte originário; subordinado porque se encontra limitado pelas normas expressas e implícitas do texto 
constitucional, às quais não poderá contrariar, sob pena de inconstitucionalidade; $e$, por fim, condicionado porque seu exercício deve seguir as regras previamente estabelecidas no texto da Constituição Federal. (Moraes, 2001, p. 55).

Pontes de Miranda (1973) acresce outro conceito quando trata do Poder Constituinte. Segundo o autor, importa analisar também o Poder Estatal. Este seria "o poder de construir e reconstruir o Estado" (Pontes de Miranda, 1973, p.175). Difere do primeiro, pois este é o "o poder de construir o Estado" e aquele "o poder de constituí-lo". O Poder Estatal abrange "também os atos pré-constitucionais, os de constituição e os pós-constitucionais, normais ou não" (Pontes de Miranda, 1973, p.187). De forma resumida, ao unir considerações sobre o poder estatal, constituinte e a constituição, o autor enuncia: "O poder estatal diz quem faz a Constituição (poder constituinte) e o poder constituinte dita a Constituição. O poder estatal está em todo o povo, desde que "ao povo pertence". O poder constituinte pode ser popular ou não. A Constituição é a lei primeira, a lei principal, a lei superior'(Pontes de Miranda, 1973, p.259). Assim, tal conceito, embora não comum no resto da doutrina, pode incrementar a densidade das considerações teóricas.

Nesse ínterim, o Congresso Nacional, por onde tramitam as Emendas à Constituição, é compreendido como poder constituinte derivado, ou melhor, um poder instituído com competência constituinte derivada (Silva, 2003). Diferentemente do poder constituinte originário - que é ilimitado - ele deve seguir o regramento Constitucional e suas formalidades. Na opinião de Ferreira Filho (1985, p.105): “Tem sentido a ilimitação do Poder Constituinte quando se fala do Poder Constituinte originário, na medida em que isso significa que esse Poder não está sujeito a regra de direito positivo. Mas não tem cabimento em relação ao Poder instituído, que obviamente tem que respeitar o seu estatuto".

Já o poder constituinte originário, de titularidade do povo, após constituir o Estado (ou construí-lo, se o tomarmos por poder estatal) deixa o governo em sentido amplo ao cargo daqueles que foram instituídos. Permanece, contudo, em estado de latência. Em momentos de transição, revolução, ou mudança na idéia de Direito (Miranda, 2002) que orienta um Estado ele pode manifestar-se ou ser chamado a isso. Em tais momentos, ou seja, na manifestação do poder constituinte originário, ele age ilimitadamente, do ponto de vista do direito positivo em relação à ordem jurídica em vigor.

Interessa, nesse ponto do texto, destacar a diferença trazida por Miranda (2002) entre poder constituinte formal e material. Para o autor, da mesma forma que se pode falar em 
Constituição material e formal, há tratamento análogo no que tange ao poder constituinte. Sob a face material, seria aquele "de autoconformação do Estado segundo certa idéia de Direito"(Miranda, 2002, p.357); já no lado formal, "um poder de decretação de normas com a forma e a força jurídica próprias das normas constitucionais"(Miranda, 2002, p.357). Um decorre do outro. Não há poder formal sem seu precedente lógico (e por vezes histórico) material. É o que afirma novamente Miranda (2002, p.357): “O poder constituinte material precede o poder constituinte formal. Precede-o logicamente, porque a idéia de Direito precede a regra de Direito, o valor comanda a norma, a opção política fundamental a forma que elege para agir sobre os fatos, a legitimidade a legalidade.” Assim, não seria adequado supor que a convocação do poder constituinte originário para que se manifestasse fosse apenas do ponto de vista formal. Se convocado ou capaz de se manifestar o faz também sob a ótica material. Desse modo, quando "constitui", expressa uma idéia de Direito (material) em normas (formal).

Outro aspecto crucial refere-se aos limites da revisão constitucional. Em um sistema rígido as alterações do texto não podem ser feitas em qualquer sentido, sob pena de transformar totalmente a Constituição e modificar a própria idéia de Direito em seu bojo. Eis que surgem as limitações. Uma primeira classificação, indicada por Silva (2003), distingue limites temporais, circunstanciais e materiais. Temporal é, por exemplo, o aplicado para o caso da revisão constitucional prevista na Carta de 1988. Esta aconteceria cinco anos após a promulgação pela Assembléia Constituinte e se esgotaria. O limite encontra-se encerrado no tempo. Circunstancial, no caso brasileiro, é o que se refere à impossibilidade de reforma na vigência de intervenção federal, estado de defesa ou estado de sítio. Material, também no nosso caso, refere-se às cláusulas pétreas, que não podem ser suprimidas - ou tendidas à supressão - por Emenda Constitucional, conforme prevê o art. $60 \S 4^{\circ}$ da Constituição Federal.

Outra classificação, trazida por Ferreira Filho (1985), distingue limites de fundo, expressos e implícitos a que se submete o poder constituinte instituído. Para esse texto importam os limites implícitos. O autor, nesse ponto, refere-se à tese de Nelson de Souza Sampaio ao destacar quatro limitações dessa espécie. A primeira refere-se à manutenção dos direitos fundamentais do homem. A segunda, à inalterabilidade do titular do poder constituinte originário, ou seja, o povo. A terceira, à inalterabilidade do titular do poder constituinte instituído, que, contudo, encontra diversas ressalvas históricas ${ }^{6}$. E por fim, para o caso em tela

\footnotetext{
${ }^{6}$ Sob esse aspecto Ferreira Filho (1985) cita o caso francês da passagem da quarta para a quinta República.
} 
a mais importante, que se refere à inalterabilidade das regras que disciplinam formalmente o procedimento da alteração constitucional ${ }^{7}$.

Tendo em vista o exposto, pode-se entender, de um ponto de vista formal, pela inconstitucionalidade da PEC 157/03. Dado que feita a revisão constitucional prevista no ADCT ela esgotou sua eficácia, sendo cabível, desde então, apenas o procedimento da Emenda Constitucional como forma de revisão. Há, ainda, a limitação implícita quanto à inalterabilidade do procedimento de reforma da constituição, segundo a tese de Souza Sampaio. Também, o Congresso Nacional, sendo poder instituído com competência constituinte derivada, submete-se ao estabelecido pelo poder constituinte originário, sendo que uma alteração em contrário poderia significar usurpação de poderes por este e ruptura institucional. Nem mesmo um referendo poderia convalidar o ato, posto que ainda assim fere limitação implícita. Se o poder constituinte originário fosse chamado a se manifestar, não o deveria ser para apenas convalidar um ato (ou seja, pronunciar apenas ao final), mas sim para constituir.

Dessa forma, com uma possível aprovação da proposta, a Emenda Constitucional poderia se objeto de Ação Direta de Inconstitucionalidade. Necessário, então, que especular qual posicionamento seria adotado pelo Supremo Tribunal Federal.

O que dizer da nova idéia de convocação de uma Assembléia Constituinte exclusiva para fazer a reforma política? Sem adentrar na discussão do mérito de uma reforma política, tal iniciativa também não estaria distante da inconstitucionalidade. Sob o ponto de vista formal quanto às limitações implícitas cabem nesse caso, em certa medida, os mesmos argumentos. Ademais, numa tese ousada, poder-se-ia dizer que sendo o poder constituinte originário ilimitado, se convocado (através da escolha de representantes para uma Assembléia Constituinte) de forma limitada, ou seja, restringindo o conteúdo passível de discussão, teríamos, no caso de convalidação, a usurpação do poder constituinte por aquele que o convoca. Ou seja, o poder instituído (seja o Executivo ou o Congresso Nacional) no momento em que conclama o poder constituinte a se manifestar de forma limitada toma seu o posto. Quando este é limitado perde uma de suas características vitais deixando de ser poder

\footnotetext{
${ }^{7}$ Aqui também Ferreira Filho (1985) faz uma ressalva histórica exemplar para pensarmos a atual PEC 157/03: "Quanto à este ponto, recente polêmica se travou no Brasil. Em 1977, pela Emenda Constitucional n. 8, de 14 de abril, foi alterado o art. 48 da Constituição brasileira, para que, em vez da maioria de 213 em cada Casa do Congresso Nacional, bastasse a maioria absoluta para a aprovação de emenda constitucional. Sustentaram alguns a invalidade dessa mudança, invocando o limite implícito que Souza Sampaio aponta. A objeção, todavia, não prosperou." (Ferreira Filho, 1985, p.115)
} 
constituinte. Aquele que o limita deixa de agir como instituído para atuar como instituidor. Um poder instituído dessa forma toma em suas mãos o poder constituinte. Sob tal ponto de vista, o ex-ministro Celso Velloso poderia estar certo.

\subsection{Da Manobra política e dos atores em jogo (espaço?)}

Além da discussão doutrinária, outros aspectos merecem destaque quanto ao tema proposto. Trata-se do ponto de vista político da questão. Nesse âmbito, cabe considerar quais são os "setores revisionistas" que encaminham as propostas ora em voga, bem como suas idéias e intenções.

Quanto à Proposta que tramita na Câmara dos Deputados, ao analisar quais os propositores e defensores da idéia, bem como que argumentos utilizam, pode-se ter uma idéia de que grupo político se trata. Basicamente os apoiadores da proposta são de duas origens: aqueles que viram seu projeto derrotado pelo centro durante a Constituinte; e os defensores de uma ampla reforma do Estado brasileiro. Ambos grupos aproximam-se de posições liberais (os primeiros há mais tempo, os outros de forma um pouco tardia). Os argumentos de fundo em suas manifestações propugnam pelo "enxugamento" do texto constitucional como uma das reformas do Estado e para fins de garantir estabilidade política e governabilidade. Mas se é possível realizar tal política através das Emendas Constitucionais porque defender outra forma de revisão? Nesse aspecto a questão é tática: reduzir o quorum das votações.

Para aprovar Emendas à Constituição é preciso o voto favorável de três quintos dos membros do Congresso, em dois turnos de votação. Conforme a proposta ora apresentada tal número cairia para a maioria absoluta dos membros. Isso significa maior facilidade na aprovação das matérias. Maiorias que vencem no quorum de três quintos, vencem com maior facilidade no de maioria absoluta, podendo conter, inclusive, com um número maior de trânsfugas. Por exemplo: na Câmara dos Deputados, uma maioria com 342 membros pode ser vencedora mesmo perdendo até $10 \%$ de seus votos, num quorum de três quintos; se este passar para maioria absoluta, o mesmo grupo poderia ser vencedor mesmo perdendo até aproximadamente $20 \%$ de seus votos ${ }^{8}$. Assim, a aprovação de uma política defendida por uma

\footnotetext{
${ }^{8}$ Os números apresentados referem-se a cálculos para a Câmara dos Deputados do limites das maiorias possíveis para diferentes quoruns, levando-se em conta a taxa de risco, ou seja, o percentual de trânsfugas aceitáveis para que uma maioria seja vencedora. O procedimento adotado teve como base as fórmulas apresentadas por Grohmann (2003).
} 
maioria menor é mais fácil na segunda situação. Em se tratando de Lei Constitucional, tal fato é, no mínimo, considerável.

No que tange à idéia de convocação de Assembléia Constituinte exclusiva para aprovar a reforma política, cabem rápidas considerações do ponto de vista da análise política. Primeiramente, realizar reformas no sistema eleitoral e partidário não é tarefa fácil nem simples. Os efeitos das instituições e impacto de mudanças nem sempre são claros e unânimes na comunidade acadêmica. Mudanças institucionais devem ser cuidadosamente estudadas e elaboradas, caso contrário seus resultados podem não ser os esperados.

Também aqui se ressalta o uso tático da manifestação presidencial. Com sua declaração, o Presidente tenta novamente pautar o debate político, já em momento eleitoral, ao re-introduzir na agenda a reforma política. Dessa forma, manifesta a intenção do governo em promover as mudanças que respondam à demanda da opinião pública de um "saneamento" na política brasileira, tendo em vista as denúncias de corrupção do último período. Também, força a oposição a se manifestar sobre tal ponto. O argumento é o seguinte: já que a Congresso Nacional está maculado pela corrupção, chamemos o povo para que faça as mudanças. De pronto a oposição, parcela da própria base do governo, e a comunidade jurídica em geral manifestou contrariedade ao procedimento da constituinte exclusiva, mas adesão à reforma política. A tática funciona, em partes. Polemiza, mas pauta a agenda política.

Por fim, as considerações aqui tecidas são breves e não exaustivas do ponto de vista da análise política. De qualquer forma, merecem destaque, na medida em que contribuem, paralelamente à abordagem doutrinária, para a compreensão do fenômeno, tanto do ponto de vista jurídico como político.

\section{Considerações Finais}

O presente artigo teve a pretensão de trazer à tona a discussão acerca da revisão constitucional, seja do ponto de vista doutrinário, como da análise política, a partir dos debates acerca da PEC 157/03 e da recente declaração presidencial. O que foi exposto não é, de maneira alguma, exaustivo. Ao contrário, recoloca, parcialmente, alguns argumentos, teses e teorias sobre o tema.

Quanto à PEC 157/03 retomam-se as considerações já feitas. Há possibilidades factíveis de, se fosse aprovada, argüir sua inconstitucionalidade, do ponto de vista formal. Todavia, parece que esse não será o caso, haja vista que possivelmente a proposta não chegue a 
ser apreciada pelo plenário da Câmara. De outra banda, sob o aspecto político, é clara a intenção de, pelo expediente proposto, reduzir o quorum, tornando menos custosa a promoção de alterações constitucionais por "setores revisionistas".

No âmbito da idéia de constituinte exclusiva recentemente ventilada pelo governo, não se deve levá-la tão a sério quanto à forma. O tema da reforma política está recolocado na agenda, inclusive com peso extra, resultante da manifestação presidencial. Do ponto de vista político, como manobra, parece ter gerado algum efeito. Na ótica jurídica, contudo, não deve ser considerada fortemente viável. Nesse sentido, e seguindo a tese apresentada no texto, podese tomá-la ou como preocupante usurpação, ou como mero engodo.

\section{Referências Bibliográficas}

ALFREDO, João. Voto Contrário em Separado à Proposta de Emenda à Constituição no 157/2003, que convoca assembléia de revisão constitucional e dá outras providências. Brasília: Câmara dos Deputados, Comissão Especial, 2006. Disponível em: <http://www.camara.gov.br/sileg/Prop_Detalhe.asp?id=323029>. Acesso em: 22 jul. 2006.

BRASIL. Constituição da República Federativa do Brasil. 35ª ed. São Paulo: Saraiva, 2005.

BRASIL. Regimento Interno da Câmara dos Deputados. $6^{\mathrm{a}}$ ed. Brasília: Câmara dos Deputados, Coordenação de Publicações, 2003.

CHATELET, François. Dicionário de obras políticas. Rio de Janeiro: Civilização Brasileira, 1993.

COLLARES, Alceu. Voto Contrário em Separado à Proposta de Emenda à Constituição $\mathbf{n}^{\mathbf{0}}$ 157/2003, que convoca assembléia de revisão constitucional e dá outras providências. Brasília: Câmara dos Deputados, Comissão Especial, 2006. Disponível em: <http://www.camara.gov.br/sileg/Prop_Detalhe.asp?id=322395>. Acesso em: 22 jul. 2006.

FERRAZ JÚNIOR, Tércio Sampaio. Constituinte: assembléia, processo, poder. São Paulo: Ed. Revista dos Tribunais, 1985.

FERREIRA FILHO, Manuel Gonçalvez. O poder constituinte. $2^{a}$ ed. São Paulo: Saraiva, 1985.

GREENHAlgh, Luiz Eduardo. Voto Contrário em Separado à Proposta de Emenda à Constituição $\mathbf{n}^{\mathbf{0}} \mathbf{1 5 7 / 2 0 0 3}$, que convoca assembléia de revisão constitucional e dá outras providências. Brasília: Câmara dos Deputados, Comissão Especial, 2006. Disponível em: <http://www.camara.gov.br/sileg/Prop_Detalhe.asp?id=317291> Acesso em: 22 jul. 2006.

GROHMANN, Luis Gustavo Mello. O veto presidencial no Brasil: 1946-1964 e 1990-2000. 2003. 253f. Tese (Doutorado em Ciência Política) - Instituto Universitário de Pesquisas do Rio de Janeiro, Rio de Janeiro, 2003. 
MAGAlHÃES, Roberto. Parecer do Relator à Proposta de Emenda à Constituição no 157/2003, que convoca assembléia de revisão constitucional e dá outras providências. Brasília: Câmara dos Deputados, Comissão Especial, 2006. Disponível em: <http://www.camara.gov.br/sileg/Prop_Detalhe.asp?id=320115>. Acesso em: 22 jul. 2006.

MIRANDA, Jorge. Teoria do Estado e da Constituição. Rio de Janeiro: Forense, 2002.

MORAES, Alexandre de. Direito Constitucional. 10ª ed. São Paulo: Atlas, 2001.

MURAD, Jamil. Voto Contrário em Separado à Proposta de Emenda à Constituição no 157/2003, que convoca assembléia de revisão constitucional e dá outras providências. Brasília: Câmara dos Deputados, Comissão Especial, 2006. Disponível em: <http://www.camara.gov.br/sileg/Prop_Detalhe.asp?id=321912>. Acesso em: 22 jul. 2006.

PEREZ, Reginaldo Teixeira. O pensamento político de Roberto Campos: da razão do Estado à razão do mercado (1950-95). Rio de Janeiro: Editora FGV, 1999.

PONTES DE MIRANDA. Comentários à Constituição de 1967 com a Emenda n. 1 de 1969. Tomo I. $2^{a}$ ed. São Paulo: Ed. Revista dos Tribunais, 1973.

SANTOS, Luiz Carlos. Proposta de Emenda à Constituição $\mathbf{n}^{\mathbf{0}} \mathbf{1 5 7 / 2 0 0 3}$, que convoca assembléia de revisão constitucional e dá outras providências. Brasília: Câmara dos Deputados, 2003. Disponível em: $<$ http://www.camara.gov.br/sileg/MostrarIntegra.asp?CodTeor=160966>. Acesso em: 22 jul. 2006.

SILVA, José Afonso da. Curso de Direito Constitucional Positivo. $22^{a}$ ed. São Paulo: Malheiros, 2003.

STRECK, Lenio Luiz; CATTONI, Marcelo et al. Revisão é golpe! Porque ser contra a proposta de revisão constitucional. Jus Navigandi, Teresina, ano 10, n. 985, 13 mar. 2006. Disponível em: <http://jus2.uol.com.br/doutrina/texto.asp?id=8093>. Acesso em: 05 ago. 2006.

TEMER, Michel. Parecer do Relator à Proposta de Emenda à Constituição no 157/2003, que convoca assembléia de revisão constitucional e dá outras providências. Brasília: Câmara dos Deputados, Comissão de Constituição, Justiça e Cidadania, 2005. Disponível em: <http://www.camara.gov.br/sileg/Prop_Detalhe.asp?id=295147>. Acesso em: 22 jul. 2006. 